\title{
Concentration Determination of Extracellular and Intracellular Red Pigments Produced by Monascus sp
}

\author{
Patricia Sanae Hamano, Sandra Fernanda Bilbao Orozco and Beatriz Vahan Kilikian* \\ Departamento de Engenharia Bioquímica; Escola Politécnica da Universidade de São Paulo; Av. Lineu Prestes, \\ 580, Bloco 20; C.P: 61548; 05424-970; São Paulo - SP - Brasil
}

\begin{abstract}
In this work red pigments production was evaluated (by spectrophotometry) in semi-synthetic medium by rotary shaker cultures, utilizing seven strains of Monascus sp. The strains isolated at LEB/DEQ/EPUSP had a absorbance average of extracellular red pigments higher than the others strains (13.0 and $9.6 \mathrm{U}$, respectively) and the specific production of extracellular red pigments was from 1.7 until 3.5 times higher than the specific production of intracellular ones.
\end{abstract}

Key words: Filamentous fungi, Monascus, natural colorants, red pigments, cell disruption

\section{INTRODUCTION}

The filamentous fungus Monascus sp. produces at least six molecules of natural pigments: two yellow-colored (ankaflavin and monascin), two orange-colored (rubropunctatin and monascorubrin) and two red-colored (rubropunctamine and monascorubramine). Monascus sp. is also able to produce others secondary metabolites, like one molecule with anticholesterolemic activity, antibiotics and antitumorals (Juslová et al., 1996). This fungus has been used for producing soya bean cheese, red rice wine and anka (red rice) in various Asian countries (principally in Japan and China) for many hundreds of years.

The interest in red pigments of Monascus sp. has been growing up by food industry because of its wide application in food (meat, fish, ketchup, liquor, etc.) and also due to the substances normally used (nitrite and nitrate salts) have carcinogenic and teratogenic effects. Some pigments produced by Monascus sp. are intracellular and insoluble in water, but the cultivation conditions (especially related with nitrogen source and $\mathrm{pH}$ ) can result in the formation of extracellular and water-soluble pigments (Yoshimura et al., 1975; Wong andKoehler, 1983; Lin andDemain, 1991; Pastrana et al., 1995; Hajjaj, 1998).

The biosynthesis mechanisms of these pigments are poorly understood (Yoshimura et al., 1975; Wong andKoehler, 1983; Lin andDemain, 1991; Pastrana et al., 1995). However, conversion of intracellular and insoluble pigments into extracellular and soluble ones can occur by a culture process that results in a higher solubilisation and increase the product recuperation in downstream process as well. A higher production also can be obtained by extraction of intracellular pigments utilizing cellular lysis methods. These techniques can be

\footnotetext{
*Author for correspondence
} 
classified as chemical, physical, enzymatic and mechanical (Middelberg, 1995). Although there are many examples of cell disruption by chemical or enzymatic process, mechanical methods are the most usually employed in industry (Kilikian andPessoa Jr., 2001). The simultaneous utilization of two or more cell breakage methods are also in focus because its synergistic action. The suitable choice for a cell disruption method depends on microorganism characteristics (i.e. cell wall composition), product to be recovered, its yield, specifity, unit operation cost and capital invested (Kilikian andPessoa Jr., 2001). The filamentous fungi have a resistant cell wall constituted basically by glucan and quitin that need high shear tension to be disrupted. As consequence of this characteristic, it was necessary to make a chemical pre-treatment with organic solvent (ethanol $70 \%$ ) and a mechanical treatment (sonifier) with Monascus sp.

The present paper intended to determine extra and intracellular red pigments concentration produced by seven strains of Monascus sp., by spectrophotometry.

\section{MATERIALS AND METHODS}

\section{Microorganisms}

Seven strains of Monascus sp. were employed in this study. Four were isolated at the Laboratório de Engenharia Bioquímica -LEB/DEQ/EPUSP (M. ruber LEB A 1-3, M. ruber LEB A 4-5, $M$. ruber LEB A 4-9 and M. ruber LEB A 5-4) and three were obtained from culture collections (M. purpureus CCT 3802, M. ruber UFPE $3196 / 2$ and M. purpureus ATCC 16365).

\section{Culture media}

Maintenance medium: Potato-dextrose-agar (PDA, Acumedia, USA).

Inoculum medium $(\mathrm{g} / \mathrm{L})$ : meat extract 3.0; peptone 5.0; glucose 10.0.

Production medium (semi-synthetic) (g/L): glucose 10.0; $\mathrm{MgSO}_{4} .7 \mathrm{H}_{2} \mathrm{O}$ 4.8; $\mathrm{KH}_{2} \mathrm{PO}_{4}$ 1.5; $\mathrm{K}_{2} \mathrm{HPO}_{4} 1.5 ; \mathrm{ZnSO}_{4} .7 \mathrm{H}_{2} \mathrm{O} \quad 0.01 ;$ monosodium glutamate 7.6; $\mathrm{NaCl} 0.4 ; \mathrm{FeSO}_{4} 0.01$; yeast extract 1.0 .

All media were prepared with distilled water and $\mathrm{pH}$ was adjusted to 5.5 prior to sterilization at $121^{\circ} \mathrm{C}$ for 20 minutes.

\section{Rotary shaker cultives}

Pre-inoculum: Monascus sp. slants on PDA were incubated for 7 days at $30^{\circ} \mathrm{C}$. Spores and hyphae were scraped off the slants using a Pasteur pipette and suspended in $4 \mathrm{~mL}$ of inoculum medium. The cell suspension was used to inoculate $100 \mathrm{~mL}$ of inoculum medium in $500 \mathrm{~mL}$ Erlenmeyer flasks, which were then incubated at $30^{\circ} \mathrm{C}, 300 \mathrm{rpm}$ in a rotary shaker for $30 \mathrm{~h}$ (time refered to final of exponential growth and beginning of secondary metabolites production).

Inoculation and cultive conditions: Each $500 \mathrm{~mL}$ Erlenmeyer flask containing $80 \mathrm{~mL}$ of the production medium (semi-synthetic) was inoculated with $20 \mathrm{~mL}$ of the inoculum culture and incubated at $30^{\circ} \mathrm{C}, 300 \mathrm{rpm}$ for 64 or $72 \mathrm{~h}$.

Sampling: Duplicate $5 \mathrm{~g}$ samples were taken at regular intervals (one for extracellular pigment and other for intracellular pigments quantification).

\section{Analytical methods}

Dry cell weight: Each sample was vacuum filtered through preweighted membrane filters (ME 28 cellulose ester membranes, Schleicher andSchuell, Germany), washed with distilled water, dried in a microwave oven (15 min, $180 \mathrm{~W})$ and mantained in a desiccator before weighing (Olsson andNielsen, 1997).

Glucose: Residual glucose concentration $(\mathrm{G})$ in the culture medium was obtained by the enzymatic method employing glucose-oxidase (Glucose GOD FS, Diasys, Diagnostic Systems International, Germany) and the results were expressed in grams per liter. The calibration curve ranged from 0.2 to $1.0 \mathrm{~g} / \mathrm{L}$.

Extracellular red pigments: Red pigment production was indirectly evaluated by means of absorbance measurements. For extracellular red pigments, absorbance measurements were performed in the filtrate obtained from dry cell concentration determination with a scanning spectrophotometer (Beckman, DU 530 UV/Vis Spectrophotometer, USA)

Intracellular red pigments: Sample was weighed and filtered through a fiberglass membrane; cellular mass was blended in $50 \mathrm{~mL}$ of ethanol $(70 \%, \mathrm{v} / \mathrm{v})$ and submitted to sonifier (Branson Sonifier, model 250, USA) for $40 \mathrm{~min}$ at $120 \mathrm{~W}$; the sample volume was filled to $50 \mathrm{~mL}$, transferred 
to a flask $(50 \mathrm{~mL})$, placed in a water bath $\left(60^{\circ} \mathrm{C}\right)$ for $2 \mathrm{~h}$ and filtrate under vacuum (ME 25 cellulose ester membranes, Schleicher andSchuell, Germany). The filtrate absorbance was measured with a scanning spectrophotometer (Beckman, DU 530 UV/Vis Spectrophotometer, USA).

Data analysis: In order to evaluate cell growth and production of red pigment for the seven strains cultivated, the following parameters were determined: red pigment specific production $\left(\mathrm{P}_{\mathrm{e}}\right)$, productivity $(\mathrm{P})$, cell yield on glucose $\left(\mathrm{Y}_{\mathrm{X} / \mathrm{G}}\right)$ and pigment yield on glucose $\left(\mathrm{Y}_{\mathrm{P} / \mathrm{G}}\right)$. These parameters were determined according to equations 1, 2, 3 and 4.

$$
\begin{aligned}
& P_{e}=\frac{A b s_{\max }}{X^{\prime}} \\
& P=\frac{A b s_{\max }}{t} \\
& Y_{X / G}=\frac{X_{\text {max }}-X_{0}}{G_{0}-G_{f}} \\
& Y_{P / G}=\frac{A b s_{\max }-A b s_{0}}{G_{0}-G_{f}}
\end{aligned}
$$

$\mathbf{P}_{\mathbf{e}}$ : extracellular red pigment specific production (U.L/g);

Abs $_{\text {max }}$ : maximum extra or intracellular red pigment absorbance at $\lambda=485-500 \mathrm{~nm}(\mathrm{U})$;

$\mathbf{X}^{\prime}$ : cell concentration at $\mathrm{t}(\mathrm{g} / \mathrm{L})$;

P: extracellular red pigment productivity $(\mathrm{U} / \mathrm{h})$;

t: time for maximum extracellular red pigment absorbance $(\mathrm{h})$;

$\mathbf{Y}_{\mathbf{X} / \mathrm{G}}$ : cell yield on glucose $(\mathrm{g} / \mathrm{g})$;

$\mathbf{X}_{\text {max }}$ : cell concentration at time $\mathrm{t}(\mathrm{g} / \mathrm{L})$;

$\mathbf{X}_{\mathbf{0}}$ : initial cell concentration $(\mathrm{g} / \mathrm{L})$;

$\mathbf{G}_{\mathbf{0}}$ : initial glucose concentration $(\mathrm{g} / \mathrm{L})$;

$\mathbf{G}_{\mathbf{f}}$ : final glucose concentration $(\mathrm{g} / \mathrm{L})$;

$\mathbf{Y}_{\mathbf{P} / \mathbf{G}}$ : red pigment yield on glucose (U.L/g);

$\mathbf{A b s}_{\mathbf{0}}$ : initial extracellular red pigment absorbance (U).

\section{RESULTS AND DISCUSSION}

Figs. 1 and 2 show cell concentration (X), glucose concentration $(\mathrm{G})$ and extracellular red pigments absorbance (Abs) of different strains.
According to Figure 1, growth phase finished during 20 and $25 \mathrm{~h}$ for all the strains and the extracellular red pigments production was not growth associated. $M$. ruber LEB A 4-9 and M. ruber LEB A 5-4 (20.4 and 14.0 U, respectively) achieved the highest absorbance values. Fig. 2 showed that the strains from culture collections had extracellular red pigments production partially growth associated.

Among these, M. ruber UFPE 3196/2 showed the highest absorbance value $(9.9 \mathrm{U})$. The absorbance average of extracellular red pigments in strains isolated at LEB was higher than from culture collections (13.0 and 9.6 U, respectively). M. ruber LEB A4-9 and $M$. ruber LEB A5-4 had the highest absorbance values of extracellular red pigments (20.4 and $14.0 \mathrm{U}$, respectively). The results obtained from cultures are shown in Table 1. The specific production allowed strain screening based on their ability to produce red pigments by mass cellular unit. $M$. ruber LEB A 4-9 and M. ruber LEB A 5-4 had the best results of $\mathrm{P}_{\mathrm{e}}(3.8$ and $2.6 \mathrm{U} . \mathrm{L} / \mathrm{g}), \mathrm{P}(0.36$ and $0.25 \mathrm{U} / \mathrm{h})$ and $\mathrm{Y}_{\mathrm{P} / \mathrm{G}}$ (1.62 and $1.11 \mathrm{U.L} / \mathrm{g}$ ), respectively.

Fig. 3 presents extra and intracellular red pigments specific production results from the seven strains. These values were calculated at the instant of maximum absorbance of red pigments. The specific production average of total red pigments (extra and intracellular) from strains isolated at LEB was higher than culture collection strains (3.4 and 2.4 U.L/g, respectively). Fig. 3 showed that $M$. ruber LEB A 4-9 and M. ruber LEB A 5-4 had the highest total red pigment specific production values (4.9 and $3.5 \mathrm{U} . \mathrm{L} / \mathrm{g}$, respectively) and the intracellular pigments represented only 21 and $24 \%$ (respectively) from these total values. The strains isolated at LEB had lower intracellular red pigments than the ones from culture collections (28 and $38 \%$, respectively). Except M. purpureus ATCC 16365 (\% of intracellular red pigments equal to 60), others strains showed specific production of extracellular red pigments higher than intracellular (average \% equal to 72.1 and 27.9, respectively), and intracellular red pigments produced by $M$. ruber UFPE $3196 / 2$ was five times lower than the extracellular one.

Extracellular red pigments are preferred because they are soluble in culture media and downstream processing is simpler and cheaper. 

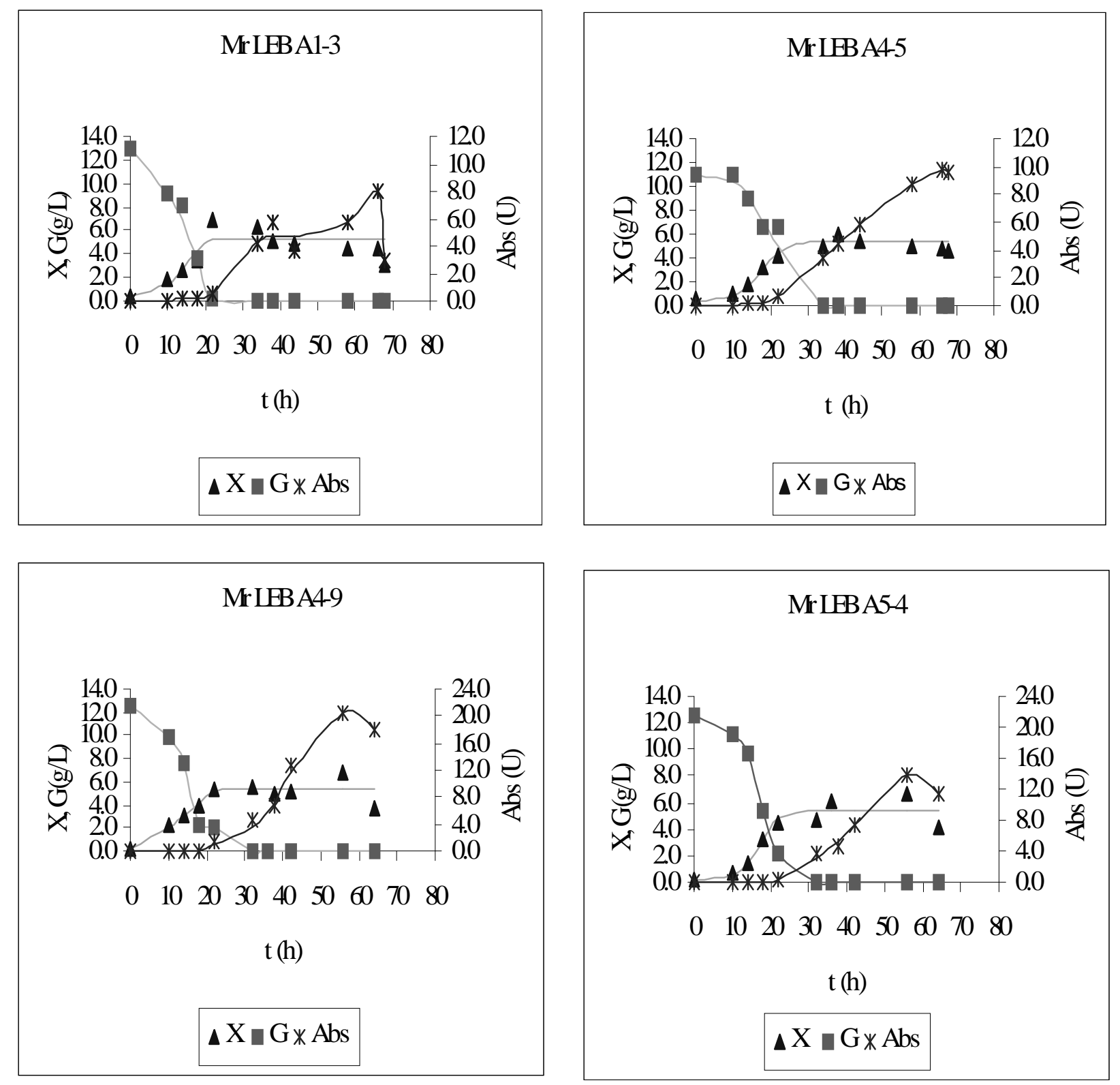

Figure 1 - Cell concentration (X), glucose concentration $(\mathrm{G})$ and extracellular red pigments absorbance (Abs) produced by M. ruber LEB A 1-3, M. ruber LEB A 4-5, M. ruber LEB A 4-9 and M. ruber LEB A 5-4. 

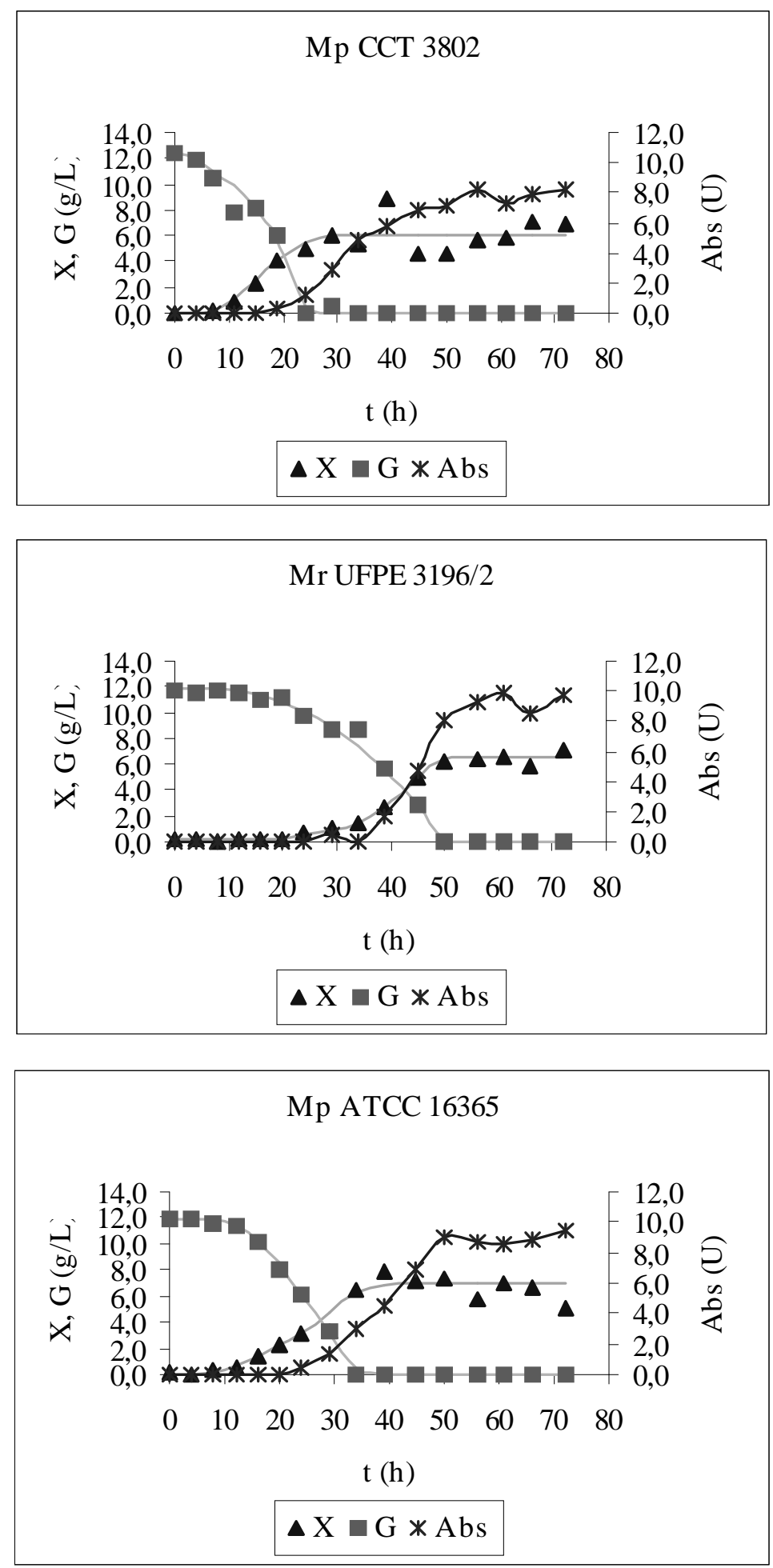

Figure 2 -Cell concentration (X), glucose concentration (G) and extracellular red pigments absorbance (Abs) produced by M. purpureus CCT 3802, M. ruber UFPE 3196/2 and M. purpureus ATCC 16365. 


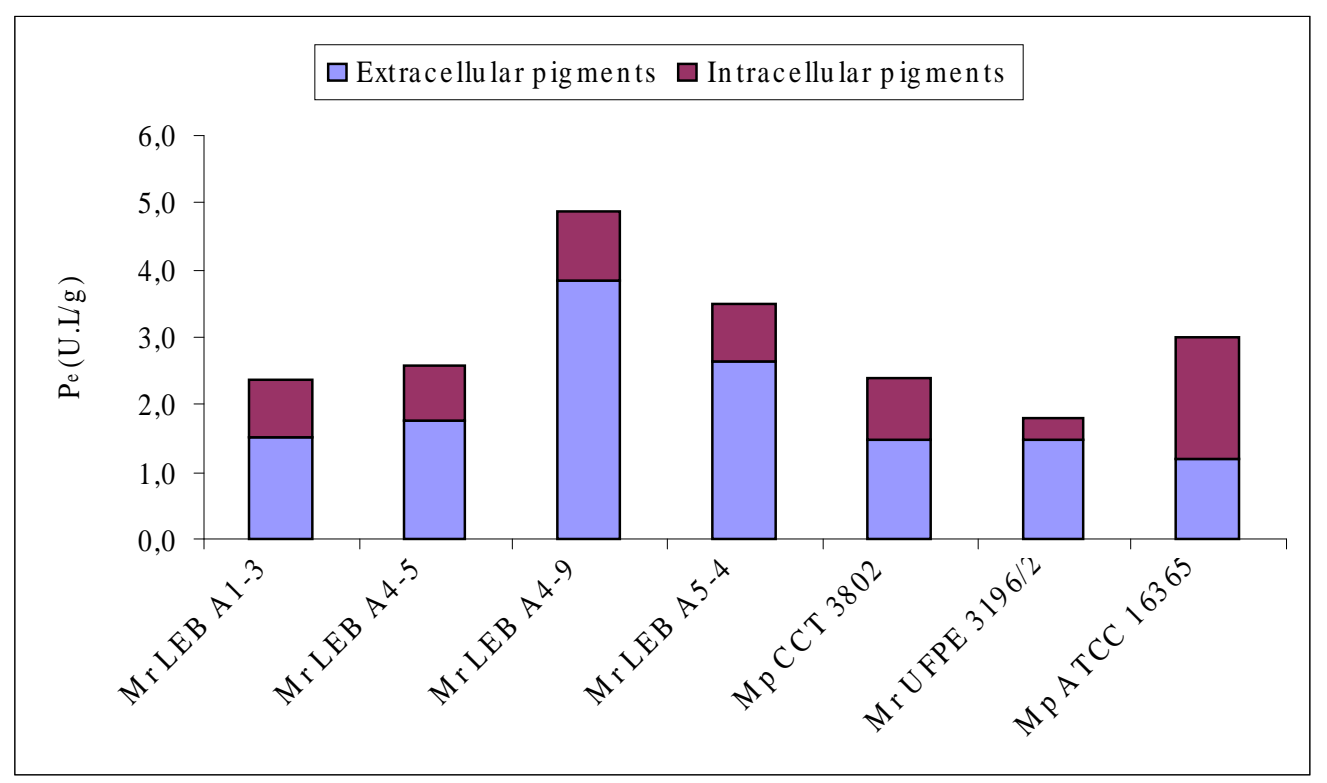

Figure 3 - Specific production of extra and intracellular red pigments.

Table 1 -Culture results relative to cell growth and extracellular red pigments production

\begin{tabular}{lcccccccc}
\hline \multicolumn{1}{c}{ Strain } & $\begin{array}{c}\mathbf{X}_{\max } \\
(\mathbf{g} / \mathbf{L})\end{array}$ & $\begin{array}{c}\mathbf{X} \\
(\mathbf{g} / \mathbf{L})\end{array}$ & $\begin{array}{c}\mathbf{A b s}_{\max } \\
(\mathbf{U})\end{array}$ & $\begin{array}{c}\mathbf{P}_{\mathbf{e}} \\
(\mathbf{U} . \mathbf{L} / \mathbf{g})\end{array}$ & $\begin{array}{c}\mathbf{P} \\
(\mathbf{U} / \mathbf{h})\end{array}$ & $\begin{array}{c}\mathbf{t} \\
(\mathbf{h})\end{array}$ & $\begin{array}{c}\mathbf{Y}_{\mathbf{X} / \mathbf{G}} \\
(\mathbf{g} / \mathbf{g})\end{array}$ & $\begin{array}{c}\mathbf{Y}_{\mathbf{P} / \mathbf{G}} \\
(\mathbf{U} . \mathbf{L} / \mathbf{g})\end{array}$ \\
\hline M. ruber A1-3 & 6.9 & 4.4 & 8.0 & 1.5 & 0.12 & 66 & 0.30 & 0.61 \\
M. ruber A4-5 & 5.9 & 4.7 & 9.7 & 1.8 & 0.15 & 66 & 0.38 & 0.88 \\
M. ruber A4-9 & 6.8 & 6.8 & 20.4 & 3.8 & 0.36 & 56 & 0.53 & 1.62 \\
M. ruber A5-4 & 6.6 & 6.6 & 14.0 & 2.6 & 0.25 & 56 & 0.51 & 1.11 \\
M. purpureus CCT 3802 & 8.8 & 5.7 & 8.2 & 1.5 & 0.15 & 56 & 0.40 & 0.66 \\
M. ruber UFPE 3196/2 & 7.1 & 6.5 & 9.9 & 1.5 & 0.16 & 61 & 0.52 & 0.84 \\
M. purpureus ATCC 16365 & 7.9 & 7.4 & 9.0 & 1.2 & 0.18 & 50 & 0.54 & 0.75 \\
\hline
\end{tabular}

\section{ACKNOWLEDGEMENTS}

We acknowledge Conselho Nacional de Desenvolvimento Científico e Tecnológico $(\mathrm{CNPq}$, Brazil) and Fundação de Amparo à Pesquisa no Estado de São Paulo (FAPESP, São Paulo, Brazil) for financial support.

\section{RESUMO}

Monascus sp. é um fungo filamentoso cuja principal aplicação industrial está relacionada à sua capacidade de produzir pigmentos vermelhos, utilizados como corantes naturais em alimentos, em substituição aos sintéticos. Neste trabalho a produção de pigmentos vermelhos foi avaliada (por meio de espectrofotometria de varredura) em meio semi-sintético, empregando sete cepas de
Monascus sp., através de cultivos conduzidos em incubador rotativo. As cepas isoladas no LEB/DEQ/EPUSP apresentaram média dos valores de absorbância dos pigmentos vermelhos extracelulares maior em relação às demais cepas (13,0 e 9,6 U, respectivamente), sendo que para as primeiras, a produção específica dos referidos pigmentos foi de 1,7 a 3,5 vezes maior que a produção específica dos pigmentos intracelulares.

\section{REFERENCES}

Hajjaj, H. (1998), Mecanismes regulant la voie de biosynthèse des polycetides (pigments rouges et toxine) chez un champignon filamenteux Monascus ruber. PhD Thesis, Toulouse University, Toulouse, France. 
Juslová, P.; Matínková, L. and Kren, V. (1996), Secondary Metabolites of the Fungus Monascus: a review. J. Ind. Microbiol., 16, 163-170.

Lin, T. F. and Demain, A. L. (1991), Effect of Nutrition of Monascus sp. on Formation of Red Pigments. Appl. Microbiol. Biotechnol., 36, 70-75.

Middelberg, A. P. J. (1995), Process-Scale Disruption of Microorganisms. Biotechnol. Adv., 13, 491-551.

Olsson, L. and Nielsen, J. (1997), On Line and in situ Monitoring of Biomass in Submerged Cultivations. Tibtech., 15, 517-522.

Pastrana, L.; Blanc, P. J.; Santerre, A. L.; Loret, M. O. and Goma, G. (1995), Production of Red Pigments by Monascus ruber in Synthetic Media with a Strictly Controlled Nitrogen Source. Proc. Biochem., 30, 333-341.

Kilikian, B. V. and Pessoa Jr., A. (2001), Purificação de Produtos Biotecnológicos. In: Biotecnologia Industrial - Engenharia Bioquímica, São Paulo : Edgard Blücher. pp. 493-522.

Wong, H. C. and Koehler, P. E. (1983), Production of Red Water-Soluble Monascus Pigments. J. Food Sci., 48, 1200-1203.

Yoshimura, M.; Yamanaka, S. and Mitsugi, K. (1975), Production of Monascus-Pigment in a Submerged Culture. Agr. Biol. Chem., 39, 1789-1795.

Received: September 29, 2004; Revised: February 25, 2005; Accepted: March 25, 2005. 